\title{
Assessment of Water Quality Index in Subarnarekha River Basin in and around Jharkhand Area
}

\author{
Nirmal Kumar Bhuyan ${ }^{1}$, Baidhar Sahu ${ }^{2}$, Swoyam P.Rout ${ }^{3}$ \\ ${ }^{l}$ Water Quality Laboratory, Central Water Commission, Bhubaneswar, 751022 \\ ${ }^{2}$ Fmr.Reader Department of Chemistry, Ravenshaw University, Cuttack,753003 \\ ${ }^{3}$ Fmr.Professor Dept. of Chemistry, Utkal University, Bhubaneswar, 751007 \\ Email of the corresponding author: liku.nirmal@gmail.com
}

\begin{abstract}
The present investigation is aimed at assessing the current water quality standard along the Subarnarekha river in Jharkhand .Eight samples were collected along the stretches of Subarnarekha basin during the period (Water Year) June-2012 to May-2013 on the first working day of every month.Various physico-chemical parameters like pH,TDS, EC,DO, BOD, Total Hardness, Total alkalinity sodium,potassium,calcium,magnesium etc. were analysed. Eight parameters namely pH,Dissolved Oxygen, Biochemical Oxygen Demand, Nitrate,Phosphate,Total Dissolved Solids and Faecal Colliform were considered to compute Water Quality Index (WQI) based on National Sanitation Foundation studies.Our findings highlighted the deterioration of water quality in the rivers due to industrialization and human activities.
\end{abstract}

Key Words: NSF Water Quality Index, TDS, EC, DO, BOD, Total Hardness, Faecal Colliform

\section{Introduction}

The study is carried out in Subarnarekha river which flows through the East Singhbhum district,which is one of the India's important industrialized areas known for ore mining, steel production, power generation, cement production and other related activities.The Subarnarekha river is the eighth river in India by its flow(12.37 billion $\mathrm{m}^{3} / \mathrm{year}$ ) and length. The River Subarnarekha is a rainfed river originating near Nagri village $\left(23^{0} 18^{1} 02^{11} \mathrm{~N}, 85^{0} 11^{1} 04^{11} \mathrm{E}\right)$ in the Ranchi district,runs through several major cities and towns such as Ranchi, Muri, Jamshedpur, Ghatshila, Adityapur etc covering a distance about $400 \mathrm{~km}$. It finally joins the Bay of Bengal at Kirtania Port $\left(21^{0} 33^{1} 18^{11} \mathrm{~N}, 87^{0} 23^{1} 32^{11} \mathrm{E}\right)$ in Odisha. Before falling in to the Bay Of Bengal the River flows through Ranchi, Saraikela and East Singhbhum district of Jharkhand, West Midnapur district of West Bengal and Balasore district of Odisha.Of its total length $269 \mathrm{~km}$ are in Jharkhand, $64 \mathrm{~km}$ in West Bengal and $62 \mathrm{~km}$ in Odisha.The Subarnarekha basin covers an area $19,300 \mathrm{~km}^{2}$.This area is nearly the $0.6 \%$ of the total national river basin area and yields $0.4 \%$ of the country's total surface water resources.Its important tributaries include Kanchi,Karkari,Kharkai and Sankh rivers.

As water is one of the most basic needs of the habitants, its safeness must be studied before use. The present study aims at detecting the quality of water in respect of Water Quality Index based on National Science Foundation Studies. The possible number of such parameters necessary to completely specify the quality of water are very large, out of which taking eight parameters in to consideration the NSF WQI is calculated from which the status of water quality can be assessed. The WQI may help in evaluating base line water quality conditions and developing trends in general water quality(Wills Martin and Irvin Kim N,1996)[1].

\begin{tabular}{|r|c|c|c|c|c|c|}
\hline Sample Code & Name of the station & River/Tributary & State & District & Latitude & Longitude \\
\hline $\mathrm{S}_{1}$ & Muri & Subarnarekha & Jharkhand & Ranchi & $22^{\circ} 48^{\prime} 56^{\prime \prime}$ & $86^{\circ} 127^{\prime \prime}$ \\
\hline $\mathrm{S}_{2}$ & Adityapur & Kharkai & Jharkhand & Purb Sighbhum & $22^{\circ} 4727^{\prime} 9^{\prime}$ & $86^{\circ} 10^{\prime} 06^{\prime \prime}$ \\
\hline $\mathrm{S}_{3}$ & Kulpatanga & Kharkai & Jharkhand & Dumka & $86^{\circ} 06^{\prime} 10^{\prime \prime}$ & $22^{\circ} 49^{\prime} 04^{\prime \prime}$ \\
\hline $\mathrm{S}_{4}$ & Jamshedpur & Subarnarekha & Jharkhand & Purb Sighbhum & $22^{\circ} 47^{\prime} 00^{\prime \prime}$ & $86^{\circ} 12^{\prime} 00^{\prime \prime}$ \\
\hline $\mathrm{S}_{5}$ & Baridhi Nalla & Subarnarekha & Jharkhand & $\begin{array}{c}\text { Paschim } \\
\text { Singhbhum }\end{array}$ & $86^{\circ} 14^{\prime} 33^{\prime \prime}$ & $22^{\circ} 49^{\prime} 05^{\prime \prime}$ \\
\hline $\mathrm{S}_{6}$ & Ghatshila & Subarnarekha & Jharkhand & Purb Sighbhum & $22^{\circ} 34^{\prime} 49^{\prime \prime}$ & $86^{\circ} 20^{\prime} 08^{\prime \prime}$ \\
\hline $\mathrm{S}_{7}$ & Ghatshila Road Bridge & Subarnarekha & Jharkhand & do & $22^{\circ} 35^{\prime} 15^{\prime \prime}$ & $86^{\circ} 27^{\prime} 12^{\prime \prime}$ \\
\hline $\mathrm{S}_{8}$ & Jamsholaghat & Subarnarekha & Jharkhand & & $22^{\circ} 13^{\prime} 08^{\prime \prime}$ & $86^{\circ} 43^{\prime} 00^{\prime \prime}$ \\
\hline
\end{tabular}

\section{Materials And Methods:}

Water samples were collected every month, from June 2012 to May 2013 from eight different stations as mentioned below, in clean and dry polythene bottles.The water samples were collected and preserved for testing of various parameters at $10^{\circ} \mathrm{C}$ throughout the period of chemical analysis. The water samples were grouped under following categories:

$\mathrm{S}_{1}=$ Subarnarekha at Muri 
$\mathrm{S}_{2}=$ Kharkai at Adityapur

$\mathrm{S}_{3}=$ Kharkai at Kulpatanga

$\mathrm{S}_{4}=$ Subarnarekha at Jamshedpur

$\mathrm{S}_{5}=$ Baridhi Nallah

$\mathrm{S}_{6}=$ Subarnarekha at Ghatshila

$\mathrm{S}_{7}=$ Subarnarekha at Ghatshila Road Bridge

$\mathrm{S}_{8}=$ Subarnarekha at Jamsholaghat

The water samples were analysed in the Central Water Commission laboratory, Bhubaneswar using standard methods(APHA 2005). The pH and Dissolved Oxygen of water samples were measured immediately after sampling at the field itself. Samples were subjected to filtration before chemical analysis. The determination of TDS was done by gravimetric process while the total hardness was carried out by EDTA complexometric titration method (APHA 2005).The Winkler's alkali iodide-azide method was followed for the estimation of DO and BOD. Nitrate was determined colorimetric procedure(APHA 2005)[2].Faecal colliform population was analysed by MPN $/ 100 \mathrm{ml}$ method by growing on M-FC medium at temperature $44.5^{\circ} \mathrm{C}$ and counted after 48 hours.

\section{National Sanitation Foundation Water Quality Index (NSFWQI):}

In order to summarize water quality data different type of WQ indices have been developed. One such index was developed by Brown et al[3] which was later referred as NSFWQI.As many as 142 WQ experts of USA were contacted and important parameters affecting water quality were assessed along with their respective weightages. Nine parameters were finally accepted to summarize the composite effect on water quality using a single numerical expression. The single numerical index helps to classify the water in to five different classes. Such classification helps to identify river water requiring immediate action on a priority basis. The parameters, their weightings, their classification and the corresponding numerical ranges are given in Tables 1 and 2 respectively.[4,5]

Table 1: NSF WQI Parameter and Weights:

\begin{tabular}{|l|l|}
\hline Parameters & WQI Weight \\
\hline Dissolved Oxygen & 0.17 \\
\hline Faecal Colliform Density & 0.15 \\
\hline $\mathrm{pH}$ & 0.12 \\
\hline $\mathrm{BOD}_{5}$ & 0.1 \\
\hline Nitrates & 0.1 \\
\hline Total Phosphates & 0.1 \\
\hline Temperature Change & 0.1 \\
\hline Turbidity & 0.08 \\
\hline Total Solids & 0.08 \\
\hline
\end{tabular}

Table 2: WQI Value Ranges ( From Mitchell and Stapp,1995)

\begin{tabular}{|l|l|}
\hline Classification & WQI Range \\
\hline Very Bad & $0-25$ \\
\hline Bad & $26-50$ \\
\hline Medium & $51-70$ \\
\hline Good & $71-90$ \\
\hline Excellent & $91-100$ \\
\hline
\end{tabular}

\section{Calculations:}

As per the requirements of NSFWQI, nine parameters were measured for each sample following the standard procedures of APHA every month. All the measured values were used in the online calculation to get their respective index values except dissolved oxygen $(\mathrm{mg} / \mathrm{l})$. The dissolved oxygen in $\mathrm{mg} / \mathrm{l}$ was converted to its percentage saturation value by using DOTABLES software. It is an online programme that converts DO in $\mathrm{mg} / \mathrm{l}$ to its percentage saturation by using sample parameters such as temperature, pressure and specific conductance. The value of the percentage saturation of dissolved oxygen was used in the online calculation to get its index value. The overall WQI is an online calculation, which is done by putting the the index values against the respective weights.[5]

\section{Result And Discussion:}

Table 3,4 and 5 give the min, max and average values of the nine measured parameters at the eight sampling points. Tables 6,7.8,9,10,11,12 and 13 gives the monthly values of these parameters and the resulting Water Quality Index of the eight sampling points During the study period the temperature remains high during summer and rainy season and low during winter. It varied within the range $22^{\circ} \mathrm{C}$ to $35^{\circ} \mathrm{C}$. The temperature variation in the river basin is about $12^{\circ} \mathrm{C}$.The $\mathrm{pH}$ of most raw water sources lies within the range of $6.5-8.5^{[3]}$.All 
the 96 water samples are found to have $\mathrm{pH}$ value within the limit. But some samples have excess $\mathrm{pH}$ value. The average $\mathrm{pH}$ value ranges from 7.3 to 8.7. The surface water of Subarnarekha at Muri has higher $\mathrm{pH}$ than the water from other sources,

Total dissolved solid at a given temperature is the material residue left in the vessel after evaporation of a filtered sample and subsequent drying in an oven. TDS contains different kinds of nutrients and have been proved to be a very useful parameter. A sudden rise in TDS content can often indicate pollution by an extraneous source. Excess amount of TDS may disturb ecological balance and causes imbalance in osmotic regulation and suffocation in aquatic fauna even in presence of a fair amount of dissolved oxygen[4].

Water containing more than $500 \mathrm{mg} / \mathrm{l}$ of TDS is not considered desirable for drinking water supply and normally less palatable and may induce an unfavorable physiological reaction in the transient consumer. In the present investigation, it is seen that TDS value of $S_{2}, S_{3}$ and $S_{5}$ were slightly ahead of the permissible limit, but water samples of other sources are within the safe limit of TDS value. Dissolved oxygen is one of the most important parameters of water quality assessment and reflects the physical and biological processes prevailing in the water and show metabolic balance. A high DO level in a community water supply is good because it makes drinking water taste better. However, high DO levels speed up corrosion in water pipes. For diverse fish population the DO level must ranges from 4-9 mg/l. However, according to European Economic Community the standard value of DO is $5 \mathrm{mg} / \mathrm{l}$ of drinking water. Except $\mathrm{S}_{5}$ all samples were contains more DO values because of domestic sewage effluents and dumping of garbage,Table-8. This causes microbiological contamination consuming the DO [6].

The degree of microbial mediated oxygen consumption in water is known as biochemical oxygen demand. This parameter is commonly measured by the quantity of oxygen utilized by suitable micro-organisms during 5 days period at $20^{\circ} \mathrm{C}$. It is not a pollutant but an indicator to what extent the water is polluted.[9] Its value $6.0 \mathrm{mg} / \mathrm{l}$ or more in water body is said to be polluted. Present study reveals that $\mathrm{S}_{1}, \mathrm{~S}_{2}, \mathrm{~S}_{5}$ samples contain more BOD values in some months, Overall the river water is not suitable for drinking purpose[7].

The parameter of greatest concern in this study appears to be Faecal Colliform .High values of Faecal Colliform were recorded at many points throught the year $(28000 \mathrm{MPN} / 100 \mathrm{ml})$ The value of nitrate was high at Baridhi ,Jamshedpur.The value of phosphate is very low in most of the places during the study.The lowest value being 0.01 in most of the places and the highest value being $0.14 \mathrm{mg} / \mathrm{l}$ at Baridhi and Jamshedpur.

Nowhere in the river stretch,water quality was found to be excellent. High values of NSFWQI was observed at the downstream of Kharkai at Kulpatanga and at the down stream of Subarnarekha at Ghatshila, Ghatshila Road Bridge and Jamsholaghat.Water quality of Subarnarekha is at its lowest from Muri to Jamshedpur region.It may be due to the industrial activities.From the months of January to June and for the months of November and December the water quality at all the sampling stations were good.[8].Water quality at the effluent Baridhi Nallah was bad almost throughout the year.During the month of August water quality at most of the stations were bad.

\section{Conclusion}

The present study reveals that the presence of Faecal Colliform in Subarnarekha basin is significant.It is due to the lack of the sanitary awareness among the inhabitants of the adjoining localities. High values of TDS during rainy seasons may be due to massive soil erosion. The poor water quality of Baridhi Nallah is due to the improper treatment of the effluents from Jamshedpur steel plant. The prime duty of the educated public should be to spread awareness in the rural as well as the urban areas. City drains connecting the safety tanks should not be allowed to directly fall in to the river. Proper treatment of the solid wastes should be made especially in urban areas. Deforestation should be strictly checked to control soil erosion due to which the TDs and Turbidity increases significantly during monsoon. Above all a long term action plan and online monitoring is a must to ensure the river water quality.[10]

\section{References}

[1]. Wills Martin and Irvin N.Kim,Middle states geographer,1996,95-104

[2]. APHA-2005,Standard Methods for the examination of water and waste water (21 $1^{\text {st }}$ edition), American Public Health Association,American Water Works Association and Water Pollution Control Fed.Washington D.C.

[3]. Brown R.M.,McLelland,N.I.Deininger,R.A. and Tozer,R.G.1970,A Water Quality Index-Do We Dare? Water and Sewage Works October:339-343

[4]. G.J. Henery and G.W. Heinke, 2005, Environmental Science Engineering ( ${ }^{\text {nd }}$ Edition), Prentice Hall of India Pvt. Ltd., New Delhi.

[5]. House,M.A. and Ellis,J.B.1987.The Development of Water Quality Indices for Operational Management.Water Science and Technology 19(9):145-154

[6]. Mukharjee,D.,Dara,S.L.and Tiwary,R.K.2012-Evaluation of water quality index for drinking water purposes in case of Damodar River,Jhadkhand and West Bengal region,India.Bioremed. Biodeg.3(9) 1000161.

[7]. Muduli,S.D.,Swain,G.D.,Bhuyan,N.K. and Dhal,N.K. (2006)-Physico-chemical characteristic assessment of Brahmani River,Orissa,India.Poll.Res. 25(4)p.763-766

[8]. Pradyusa Samantray,Basant K.Mishra,Chitta R.Panda and Swayam P. Rout Assesment of Water quality Index in Mahanadi and Artharbanki Rivers and Taladanda Canal in Paradip Area,India.

[9]. Trivedy R.K. and Goel P.K. Chemical and Biological Methods for Water Pollution Studies. ENVIRO MEDIA KARAD-415110.

[10]. Mitchell,M.K. and Stapp,W.B. 1995,Field Manual for Water Quality Monitoring.An Environmental education Programme for Schools Nineth edition.Green Project,Ann Arbor,MI 272p. 
Table No: 3

\begin{tabular}{|c|c|c|c|c|c|c|c|c|c|}
\hline \multirow[t]{3}{*}{ Parameters } & \multicolumn{9}{|c|}{$\begin{array}{llllllllll}\mathrm{C} & \mathrm{a} & \mathrm{t} & \mathrm{e} & \mathrm{g} & \mathrm{o} & \mathrm{r} & \mathrm{i} & \mathrm{e} & \mathrm{s} \\
\end{array}$} \\
\hline & \multicolumn{3}{|c|}{$S_{1}$ (Muri) } & \multicolumn{3}{|c|}{$\mathrm{S}_{2}$ (Adityapur) } & \multicolumn{3}{|c|}{$\mathrm{S}_{\mathbf{3}}$ (Kulpatanga) } \\
\hline & Min & Max & Mean & Min & Max & Mean & Min & Max & Mean \\
\hline $\mathrm{pH}$ & 7.3 & 8.7 & 7.85 & 7.3 & 8.0 & 7.57 & 7.4 & 8.1 & 7.80 \\
\hline Turbidity & 1.6 & 328 & 95.0 & 2.4 & 520 & 103.57 & 1.8 & 482 & 97.5 \\
\hline Total solids & 143 & 455 & 219.3 & 143 & 650.6 & 279.1 & 143 & 118.5 & 318.8 \\
\hline D.O. & 1.6 & 7.9 & 6.55 & 2.0 & 8.9 & 6.06 & 5.4 & 8.3 & 6.75 \\
\hline B.O.D & 0.2 & 19.9 & 2.44 & 0.4 & 39.6 & 4.48 & 0.1 & 1.8 & 0.89 \\
\hline Faecal Colliform MPN/100ml & 1200 & 28000 & 4641 & 620 & 4300 & 1569 & 220 & 5300 & 1469 \\
\hline Total phosphate & 0.01 & 0.08 & 0.05 & 0.01 & 0.16 & 0.05 & 0.01 & 0.09 & 0.04 \\
\hline Nitrate & 0.18 & 0.96 & 0.61 & 0.36 & 1.94 & 0.80 & 0.18 & 1.21 & 0.60 \\
\hline WQI & 44 & 79 & 69 & 49 & 78 & 70 & 70 & 79 & 74 \\
\hline
\end{tabular}

Table No: 4

\begin{tabular}{|c|c|c|c|c|c|c|c|c|c|}
\hline \multirow{2}{*}{ Parameters } & \multicolumn{3}{|c|}{$\mathbf{S}_{\mathbf{4}}$ (Jamshedpur) } & \multicolumn{3}{|c|}{ S $_{\mathbf{5}}($ Baridhi Nallah) } & \multicolumn{3}{c|}{$\mathbf{S}_{\mathbf{6}}(\mathbf{G h a t s h i l a )}$} \\
\cline { 2 - 10 } & Min & Max & Mean & Min & Max & Mean & Min & Max & Mean \\
\hline pH & 7.1 & 7.7 & 7.49 & 6.9 & 7.5 & 7.30 & 6.2 & 8.4 & 7.50 \\
\hline Turbidity & 1.4 & 490 & 128.5 & 28.6 & 560 & 156.0 & 1.8 & 320 & 79.6 \\
\hline Total Solids & 130 & 195 & 147.9 & 149.5 & 754 & 389.45 & 92.95 & 572 & 218.99 \\
\hline DO & 4.8 & 7.0 & 6.00 & 0.0 & 7.6 & 3.23 & 2.8 & 10.3 & 6.45 \\
\hline BOD & 0.3 & 2.2 & 1.09 & 0.4 & 59.8 & 17.35 & 0.4 & 1.4 & 0.79 \\
\hline Faecal Colliform MPN/100ml & 240 & 7000 & 2157 & 1100 & 24000 & 5463 & 170 & 4600 & 1350 \\
\hline Total phosphate & 0.01 & 0.14 & 0.06 & 0.02 & 0.24 & 0.06 & 0.01 & 0.06 & 0.02 \\
\hline Nitrate & 0.12 & 0.83 & 0.43 & 0.32 & 1.38 & 0.51 & 0.24 & 1.26 & 0.81 \\
\hline WQI & 68 & 78 & 73 & 40 & 73 & 56 & 61 & 78 & 73 \\
\hline
\end{tabular}

Table No: 5

\begin{tabular}{|c|c|c|c|c|c|c|}
\hline \multirow[t]{2}{*}{ Parameters } & \multicolumn{3}{|c|}{ S $_{7}$ (Ghatshila Rd Bdge) } & \multicolumn{3}{|c|}{$\mathbf{S}_{8}($ Jamsholaghat $)$} \\
\hline & Min & $\operatorname{Max}$ & Mean & Min & Max & Mean \\
\hline pH & 7.4 & 8.5 & 7.70 & 7.2 & 8.0 & 7.50 \\
\hline Turbidity & 1.6 & 392 & 102.5 & 1.2 & 285 & 84.41 \\
\hline Total solids & 143 & 292.5 & 213.41 & 148 & 253 & 196.45 \\
\hline D.O. & 4.8 & 10.1 & 6.9 & 5.2 & 6.6 & 5.85 \\
\hline B.O.D & 0.2 & 3.0 & 0.96 & 0.2 & 1.2 & 0.58 \\
\hline Faecal Colliform MPN/100ml & 220 & 3800 & 1458 & 620 & 4200 & 1546 \\
\hline Total phosphate & 0.01 & 0.12 & 0.03 & 0.01 & 0.18 & 0.04 \\
\hline Nitrate & 0.38 & 1.26 & 0.79 & 0.24 & 1.18 & 0.65 \\
\hline WQI & 69 & 79 & 73 & 68 & 78 & 70 \\
\hline
\end{tabular}

Table No: 6 Monthly Water Quality Index at Muri

\begin{tabular}{|c|c|c|c|c|c|c|c|c|c|c|c|c|}
\hline Parameters & $\begin{array}{l}\text { June } \\
2012 \\
\end{array}$ & $\begin{array}{c}\text { Jul } \\
2012\end{array}$ & $\begin{array}{l}\text { Aug } \\
2012 \\
\end{array}$ & $\begin{array}{c}\text { Sep } \\
2012\end{array}$ & $\begin{array}{c}\text { Oct } \\
2012 \\
\end{array}$ & $\begin{array}{l}\text { Nov } \\
2012 \\
\end{array}$ & $\begin{array}{c}\text { Dec } \\
2012 \\
\end{array}$ & $\begin{array}{c}\text { Jan } \\
2013\end{array}$ & $\begin{array}{c}\text { Feb } \\
2013 \\
\end{array}$ & $\begin{array}{l}\text { Mar } \\
2013 \\
\end{array}$ & $\begin{array}{c}\text { Apr } \\
2013\end{array}$ & $\begin{array}{l}\text { May } \\
2013 \\
\end{array}$ \\
\hline $\mathrm{pH}$ & 8.4 & 7.7 & 7.9 & 7.6 & 7.6 & 7.3 & 7.7 & 7.4 & 8.0 & 7.9 & 8.7 & 8.0 \\
\hline Turbidity & 42.6 & 132 & 168 & 328 & 280 & 128 & 32 & 12 & 8.2 & 6.8 & 1.6 & 1.2 \\
\hline Total solids & 286 & 279.5 & 162.5 & 162.5 & 149.5 & 149.5 & 208 & 143 & 156 & 175.5 & 305.5 & 455 \\
\hline D.O. & 6.6 & 1.6 & 6.6 & 7.0 & 6.0 & 7.6 & 7.9 & 7.9 & 7.9 & 6.8 & 6.8 & 6.0 \\
\hline B.O.D & 2.2 & 19.9 & 0.4 & 1.2 & 0.4 & 0.6 & 0.6 & 0.2 & 0.4 & 0.4 & 2.6 & 0.4 \\
\hline $\begin{array}{c}\text { Faecal Colliform } \\
\text { MPN/100ml }\end{array}$ & 4000 & 5200 & 1800 & 1200 & 1100 & 1600 & 28000 & 1200 & 3200 & 2400 & 2800 & 3200 \\
\hline Total phosphate & 0.04 & 0.06 & 0.08 & 0.06 & 0.01 & 0.02 & 0.06 & 0.08 & 0.04 & 0.06 & 0.08 & 0.02 \\
\hline Nitrate & 0.42 & 0.54 & 0.18 & 0.56 & 0.62 & 0.74 & 0.42 & 0.82 & 0.94 & 0.68 & 0.73 & 0.96 \\
\hline WQI & 67 & 44 & 69 & 70 & 69 & 73 & 75 & 79 & 78 & 76 & 61 & 72 \\
\hline Classification & Med & $\mathrm{Bad}$ & Med & Good & Med & Good & Good & Good & Good & Good & Med & Good \\
\hline
\end{tabular}

Table No: 7 Monthly Water Quality Index at Adityapur

\begin{tabular}{|c|c|c|c|c|c|c|c|c|c|c|c|c|}
\hline Parameters & $\begin{array}{l}\text { June } \\
2012 \\
\end{array}$ & \begin{tabular}{|c|} 
Jul \\
2012 \\
\end{tabular} & $\begin{array}{l}\text { Aug } \\
2012 \\
\end{array}$ & $\begin{array}{l}\text { Sep } \\
2012\end{array}$ & $\begin{array}{c}\text { Oct } \\
2012 \\
\end{array}$ & $\begin{array}{l}\text { Nov } \\
2012 \\
\end{array}$ & $\begin{array}{c}\text { Dec } \\
2012 \\
\end{array}$ & \begin{tabular}{|l} 
Jan \\
2013 \\
\end{tabular} & $\begin{array}{c}\text { Feb } \\
2013 \\
\end{array}$ & $\begin{array}{l}\text { Mar } \\
2013 \\
\end{array}$ & $\begin{array}{c}\text { Apr } \\
2013\end{array}$ & $\begin{array}{l}\text { May } \\
2013 \\
\end{array}$ \\
\hline $\mathrm{pH}$ & 7.6 & 7.8 & 7.7 & 8.0 & 7.9 & 7.5 & 7.5 & 7.3 & 7.6 & 7.4 & 7.3 & 7.3 \\
\hline Turbidity & 32.4 & 122.6 & 520 & 320 & 180 & 36.2 & 12.4 & 8.2 & 2.4 & 2.8 & 3.2 & 2.7 \\
\hline Total solids & 487.5 & 143 & 111.2 & 143 & 169 & 169 & 188.5 & 214.5 & 279.5 & 318.5 & 650.5 & 474.5 \\
\hline D.O. & 2.0 & 6.0 & 5.8 & 6.8 & 6.2 & 7.9 & 8.9 & 7.0 & 6.2 & 3.2 & 5.8 & 7.0 \\
\hline B.O.D & 39.6 & 1.8 & 0.6 & 1.2 & 0.4 & 0.8 & 1.6 & 2.0 & 3.0 & 0.4 & 0.4 & 2.0 \\
\hline $\begin{array}{c}\text { Faecal Colliform } \\
\text { MPN/100ml }\end{array}$ & 920 & 740 & 830 & 620 & 960 & 1800 & 2400 & 4300 & 2100 & 1230 & 1520 & 1410 \\
\hline Total phosphate & 0.04 & 0.08 & 0.01 & 0.06 & 0.12 & 0.02 & 0.01 & 0.01 & 0.16 & 0.02 & 0.04 & 0.01 \\
\hline Nitrate & 0.46 & 0.52 & 0.52 & 0.38 & 0.36 & 0.82 & 0.98 & 0.84 & 1.94 & 0.78 & 0.92 & 1.10 \\
\hline WQI & 49 & 68 & 69 & 70 & 68 & 76 & 78 & 74 & 71 & 68 & 71 & 73 \\
\hline Classification & $\mathrm{Bad}$ & Med & Med & Good & Med & Good & Good & Good & Good & Med & Good & Good \\
\hline
\end{tabular}


Assessment of Water Quality Index in Subarnarekha River Basin in and around Jharkhand Area

Table No: 8 Monthly Water Quality Index at Kulpatanga

\begin{tabular}{|c|c|c|c|c|c|c|c|c|c|c|c|c|}
\hline Parameters & $\begin{array}{l}\text { June } \\
2012\end{array}$ & $\underset{2012}{\text { Jul }}$ & $\begin{array}{l}\text { Aug } \\
2012\end{array}$ & $\begin{array}{c}\text { Sep } \\
2012\end{array}$ & $\begin{array}{c}\text { Oct } \\
2012\end{array}$ & $\begin{array}{l}\text { Nov } \\
2012\end{array}$ & $\begin{array}{c}\text { Dec } \\
2012\end{array}$ & $\begin{array}{c}\text { Jan } \\
2013\end{array}$ & $\begin{array}{c}\text { Feb } \\
2013\end{array}$ & $\begin{array}{l}\text { Mar } \\
2013\end{array}$ & $\begin{array}{c}\text { Apr } \\
2013\end{array}$ & $\begin{array}{l}\text { May } \\
2013\end{array}$ \\
\hline $\mathrm{pH}$ & 8.1 & 7.9 & 7.7 & 7.8 & 8.0 & 7.4 & 7.4 & 7.6 & 8.1 & 8.0 & 7.9 & 7.9 \\
\hline Turbidity & 24.6 & 116 & 181 & 482 & 260 & 62 & 16.2 & 12.6 & 8.6 & 1.8 & 2.8 & 2.4 \\
\hline Total solids & 214.5 & 143 & 108.5 & 149.5 & 162.5 & 149.5 & 182 & 175.5 & 182 & 188.5 & 234 & 240.5 \\
\hline D.O. & 5.4 & 6.0 & 5.4 & 6.4 & 8.1 & 7.4 & 8.3 & 7.0 & 7.9 & 7.0 & 6.8 & 5.4 \\
\hline B.O.D & 1.2 & 1.0 & 0.4 & 0.8 & 1.8 & 0.6 & 1.8 & 0.2 & 0.6 & 0.4 & 1.0 & 1.0 \\
\hline $\begin{array}{l}\text { Faecal Colliform } \\
\text { MPN/100ml }\end{array}$ & 720 & 430 & 380 & 220 & 620 & 1800 & 2100 & 5300 & 2400 & 1260 & 1300 & 1100 \\
\hline Total phosphate & 0.01 & 0.01 & 0.02 & 0.06 & 0.04 & 0.02 & 0.01 & 0.05 & 0.09 & 0.01 & .04 & 0.01 \\
\hline Nitrate & 0.62 & 0.72 & .52 & .24 & 0.18 & 0.32 & 0.48 & 0.84 & 0.62 & 1.21 & 0.81 & 0.68 \\
\hline WQI & 71 & 71 & 70 & 73 & 72 & 75 & 77 & 76 & 77 & 79 & 78 & 74 \\
\hline Classification & Good & Good & Good & Good & Good & Good & Good & Good & Good & Good & Good & Good \\
\hline
\end{tabular}

Table No: 9 Monthly Water Quality Index at Jamshedpur

\begin{tabular}{|c|c|c|c|c|c|c|c|c|c|c|c|c|}
\hline Parameters & $\begin{array}{l}\text { June } \\
2012 \\
\end{array}$ & $\underset{2012}{\text { Jul }}$ & $\begin{array}{l}\text { Aug } \\
2012 \\
\end{array}$ & $\begin{array}{c}\text { Sep } \\
2012 \\
\end{array}$ & $\begin{array}{r}\text { Oct } \\
2012 \\
\end{array}$ & $\begin{array}{l}\text { Nov } \\
2012 \\
\end{array}$ & $\begin{array}{c}\text { Dec } \\
2012 \\
\end{array}$ & $\begin{array}{c}\text { Jan } \\
2013 \\
\end{array}$ & $\begin{array}{c}\text { Feb } \\
2013 \\
\end{array}$ & $\begin{array}{l}\text { Mar } \\
2013 \\
\end{array}$ & $\begin{array}{l}\text { Apr } \\
2013\end{array}$ & $\begin{array}{l}\text { May } \\
2013 \\
\end{array}$ \\
\hline $\mathrm{pH}$ & 7.7 & 7.7 & 7.5 & 7.5 & 7.7 & 7.6 & 7.1 & 7.3 & 7.5 & 7.6 & 7.4 & 7.3 \\
\hline Turbidity & 34.6 & 180 & 360 & 490 & 360 & 82 & 18.6 & 8.6 & 2.8 & 1.4 & 1.8 & 1.6 \\
\hline Total solids & 162.5 & 149.5 & 136.7 & 130 & 130 & 175.5 & 195 & 156 & 162.5 & 175.5 & 156 & 169 \\
\hline D.O. & 5.4 & 6.8 & 4.8 & 6.0 & 7.0 & 5.0 & 6.0 & 7.2 & 6.4 & 6.4 & 6.2 & 4.8 \\
\hline B.O.D & 2.2 & 1.0 & 0.8 & 2.0 & 0.4 & 0.8 & 1.2 & 0.6 & 0.8 & 1.0 & 2.0 & 0.6 \\
\hline $\begin{array}{c}\text { Faecal Colliform } \\
\text { MPN/100ml }\end{array}$ & 920 & 560 & 410 & 360 & 240 & 380 & 4000 & 4600 & 7000 & 3200 & 2400 & 1820 \\
\hline Total phosphate & 0.01 & 0.02 & 0.01 & 0.04 & 0.08 & 0.06 & 0.01 & 0.12 & 0.14 & 0.08 & 0.06 & 0.04 \\
\hline Nitrate & 0.28 & 0.32 & 0.24 & 0.12 & 0.18 & 0.78 & 0.83 & 0.76 & 0.64 & 0.46 & 0.32 & 0.28 \\
\hline WQI & 69 & 73 & 68 & 70 & 75 & 69 & 73 & 78 & 76 & 78 & 76 & 73 \\
\hline Classification & Med & Good & Med & Good & Good & Med & Good & Good & Good & Good & Good & Good \\
\hline
\end{tabular}

Table No: 10 Monthly Water Quality Index at Baridhi Nallah

\begin{tabular}{|c|c|c|c|c|c|c|c|c|c|c|c|c|}
\hline Parameters & $\begin{array}{l}\text { June } \\
2012\end{array}$ & $\begin{array}{c}\text { Jul } \\
2012\end{array}$ & $\begin{array}{l}\text { Aug } \\
2012\end{array}$ & $\begin{array}{c}\text { Sep } \\
2012\end{array}$ & $\begin{array}{c}\text { Oct } \\
2012\end{array}$ & $\begin{array}{l}\text { Nov } \\
2012\end{array}$ & $\begin{array}{l}\text { Dec } \\
2012\end{array}$ & $\begin{array}{c}\text { Jan } \\
2013\end{array}$ & $\begin{array}{l}\text { Feb } \\
2013\end{array}$ & $\begin{array}{l}\text { Mar } \\
2013\end{array}$ & $\begin{array}{l}\text { Apr } \\
2013\end{array}$ & $\begin{array}{l}\text { May } \\
2013\end{array}$ \\
\hline $\mathrm{pH}$ & 7.4 & 7.5 & 7.4 & 7.0 & 7.7 & 7.0 & 7.2 & 6.9 & 7.4 & 7.5 & 7.2 & 7.4 \\
\hline Turbidity & 152 & 280 & 560 & 362 & 260 & 48.6 & 38.2 & 28.6 & 36.1 & 47.2 & 30.2 & 29.4 \\
\hline Total solids & 650 & 520 & 559 & 253.5 & 149.5 & 208 & 195 & 169 & 520 & 754 & 520 & 175.5 \\
\hline D.O. & 0.0 & 2.8 & 0.0 & 3.0 & 6.6 & 7.6 & 7.6 & 6.0 & 4.0 & 0.0 & 0.0 & 1.2 \\
\hline B.O.D & 59.8 & 19.9 & 60.0 & 40.0 & 0.8 & 2.0 & 1.6 & 1.8 & 1.6 & 0.4 & 20.0 & 0.4 \\
\hline $\begin{array}{c}\text { Faecal Colliform } \\
\text { MPN/100ml }\end{array}$ & 1800 & 1960 & 1100 & 1260 & 1300 & 2400 & 12000 & 9500 & 24000 & 4200 & 3640 & 2400 \\
\hline Total phosphate & 0.02 & 0.02 & 0.01 & 0.06 & 0.04 & 0.08 & 0.08 & 0.14 & 0.08 & 0.06 & 0.06 & 0.01 \\
\hline Nitrate & 0.32 & 0.47 & 0.68 & 0.12 & 0.43 & 0.80 & 0.71 & 0.68 & 0.52 & 0.46 & 0.42 & 0.51 \\
\hline WQI & 40 & 44 & 40 & 47 & 71 & 71 & 73 & 69 & 59 & 53 & 44 & 61 \\
\hline Classification & $\mathrm{Bad}$ & $\mathrm{Bad}$ & $\mathrm{Bad}$ & $\mathrm{Bad}$ & Good & Good & Good & Med & Med & Med & $\mathrm{Bad}$ & Med \\
\hline
\end{tabular}

Table No: 11 Monthly Water Quality Index at Ghatshila

\begin{tabular}{|c|c|c|c|c|c|c|c|c|c|c|c|c|}
\hline Parameters & $\begin{array}{l}\text { June } \\
2012\end{array}$ & $\begin{array}{c}\text { Jul } \\
2012\end{array}$ & $\begin{array}{l}\text { Aug } \\
2012\end{array}$ & $\begin{array}{c}\text { Sep } \\
2012\end{array}$ & $\begin{array}{l}\text { Oct } \\
2012\end{array}$ & $\begin{array}{l}\text { Nov } \\
2012\end{array}$ & $\begin{array}{c}\text { Dec } \\
2012\end{array}$ & $\begin{array}{c}\text { Jan } \\
2013\end{array}$ & $\begin{array}{c}\text { Feb } \\
2013\end{array}$ & $\begin{array}{l}\text { Mar } \\
2013\end{array}$ & $\begin{array}{c}\text { Apr } \\
2013\end{array}$ & $\begin{array}{l}\text { May } \\
2013\end{array}$ \\
\hline $\mathrm{pH}$ & 7.4 & 7.4 & 7.4 & 6.2 & 7.7 & 7.3 & 7.7 & 7.9 & 8.4 & 7.4 & 7.7 & 8.0 \\
\hline Turbidity & 28.2 & 210 & 128 & 320 & 168 & 65 & 18.2 & 8.3 & 3.2 & 1.8 & 1.9 & 2.8 \\
\hline D.O. & 5.5 & 5.4 & 4.4 & 6.2 & 6.2 & 8.3 & 10.3 & 8.3 & 7.9 & 2.8 & 6.8 & 5.4 \\
\hline B.O.D & 0.7 & 0.8 & 1.4 & 0.6 & 0.4 & 1.4 & 0.6 & 0.6 & 0.4 & 0.8 & 1.2 & 0.6 \\
\hline $\begin{array}{c}\text { Faecal Colliform } \\
\text { MPN/100ml }\end{array}$ & 960 & 420 & 320 & 170 & 460 & 420 & 2100 & 2400 & 1500 & 4600 & 1600 & 1260 \\
\hline Total phosphate & 0.02 & 0.04 & 0.01 & 0.01 & 0.01 & 0.04 & 0.01 & 0.06 & 0.01 & 0.01 & 0.02 & 0.01 \\
\hline Nitrate & 0.38 & 0.72 & 0.64 & 0.58 & 0.56 & 0.92 & 0.83 & 0.94 & 1.26 & 0.95 & 1.12 & 0.93 \\
\hline WQI & 73 & 69 & 66 & 70 & 72 & 77 & 75 & 78 & 78 & 61 & 78 & 74 \\
\hline Classification & Good & Med & Med & Good & Good & Good & Good & Good & Good & Med & Good & Good \\
\hline
\end{tabular}


Assessment of Water Quality Index in Subarnarekha River Basin in and around Jharkhand Area

Table No: 12 Monthly Water Quality Index at Ghatshila Road Bridge

\begin{tabular}{|c|c|c|c|c|c|c|c|c|c|c|c|c|}
\hline Parameters & $\begin{array}{l}\text { June } \\
2012\end{array}$ & $\underset{2012}{\text { Jul }}$ & $\begin{array}{l}\text { Aug } \\
2012\end{array}$ & $\begin{array}{c}\text { Sep } \\
2012\end{array}$ & $\begin{array}{r}\text { Oct } \\
2012\end{array}$ & $\begin{array}{l}\text { Nov } \\
2012\end{array}$ & $\begin{array}{c}\text { Dec } \\
2012\end{array}$ & $\begin{array}{c}\text { Jan } \\
2013\end{array}$ & $\begin{array}{c}\text { Feb } \\
2013\end{array}$ & $\begin{array}{l}\text { Mar } \\
2013\end{array}$ & $\begin{array}{l}\text { Apr } \\
2013\end{array}$ & $\begin{array}{l}\text { May } \\
2013\end{array}$ \\
\hline $\mathrm{pH}$ & 7.6 & 7.6 & 7.5 & 7.4 & 7.6 & 7.5 & 7.6 & 7.7 & 8.5 & 7.8 & 8.1 & 7.9 \\
\hline Turbidity & 63 & 280 & 392 & 240 & 182 & 52 & 8.6 & 3.2 & 1.6 & 1.8 & 2.8 & 2.4 \\
\hline Total solids & 234 & 195 & 175.5 & 143 & 149.5 & 273 & 260 & 214.5 & 214.5 & 292.5 & 156 & 253.5 \\
\hline D.O. & 5.6 & 5.8 & 5.2 & 6.0 & 6.4 & 8.3 & 8.5 & 7.9 & 10.1 & 6.4 & 8.5 & 4.8 \\
\hline B.O.D & 0.4 & 1.2 & 1.2 & 0.2 & 0.8 & 1.0 & 0.6 & 0.2 & 2.0 & 0.4 & 3.0 & 0.6 \\
\hline $\begin{array}{c}\text { Faecal Colliform } \\
\text { MPN/100ml }\end{array}$ & 1100 & 640 & 560 & 220 & 650 & 830 & 2100 & 3000 & 3600 & 1600 & 1800 & 1400 \\
\hline Total phosphate & 0.01 & 0.01 & 0.02 & 0.01 & 0.06 & 0.01 & 0.01 & 0.12 & 0.08 & 0.01 & 0.01 & 0.01 \\
\hline Nitrate & 0.78 & 0.86 & 0.54 & 0.38 & 0.46 & 0.82 & 0.92 & 0.82 & 1.26 & 0.96 & 0.82 & 0.88 \\
\hline WQI & 70 & 69 & 67 & 73 & 72 & 76 & 79 & 79 & 73 & 77 & 76 & 72 \\
\hline Classification & Good & Med & Med & Good & Good & Good & Good & Good & Good & Good & Good & Good \\
\hline
\end{tabular}

Table No: 13 Monthly Water Quality Index at Jamsholaghat

\begin{tabular}{|c|c|c|c|c|c|c|c|c|c|c|c|c|}
\hline Parameters & $\begin{array}{l}\text { June } \\
2012\end{array}$ & $\underset{2012}{\text { Jul }}$ & $\begin{array}{l}\text { Aug } \\
2012\end{array}$ & $\begin{array}{c}\text { Sep } \\
2012\end{array}$ & $\begin{array}{c}\text { Oct } \\
2012\end{array}$ & $\begin{array}{c}\text { Nov } \\
2012\end{array}$ & $\begin{array}{c}\text { Dec } \\
2012\end{array}$ & $\begin{array}{c}\text { Jan } \\
2013\end{array}$ & $\begin{array}{c}\text { Feb } \\
2013\end{array}$ & $\begin{array}{l}\text { Mar } \\
2013\end{array}$ & $\begin{array}{c}\text { Apr } \\
2013\end{array}$ & $\begin{array}{l}\text { May } \\
2013 \\
\end{array}$ \\
\hline $\mathrm{pH}$ & 7.5 & 7.3 & 7.3 & 7.2 & 7.7 & 7.8 & 7.5 & 8.0 & 8.0 & 7.3 & 7.8 & 7.6 \\
\hline Turbidity & 25.6 & 240 & 285 & 260 & 120 & 52 & 16.2 & 5.2 & 3.2 & 1.2 & 1.8 & 2.8 \\
\hline Total solids & 228 & 196 & 178 & 138 & 162 & 281 & 253 & 188 & 125.5 & 218 & 148 & 242 \\
\hline D.O. & 5.3 & 5.2 & 6.2 & 5.8 & 6.6 & 5.4 & 6.1 & 5.8 & 5.6 & 6.1 & 6.4 & 5.8 \\
\hline B.O.D & 0.4 & 0.6 & 0.4 & 0.6 & 0.8 & 1.2 & 0.6 & 0.2 & 0.4 & 0.2 & 1.2 & 0.4 \\
\hline $\begin{array}{l}\text { Faecal Colliform } \\
\text { MPN/100ml }\end{array}$ & 720 & 640 & 620 & 800 & 860 & 1800 & 4200 & 3400 & 1800 & 1200 & 1560 & 960 \\
\hline Total phosphate & 0.01 & 0.01 & 0.06 & 0.06 & 0.08 & 0.01 & 0.01 & 0.12 & 0.06 & 0.01 & 0.04 & 0.01 \\
\hline Nitrate & 0.52 & 0.46 & 0.32 & 0.24 & 0.38 & 0.68 & 0.86 & 0.92 & 1.18 & 0.84 & 0.68 & 0.72 \\
\hline WQI & 72 & 68 & 71 & 70 & 71 & 68 & 74 & 74 & 75 & 78 & 78 & 76 \\
\hline Classification & Good & Med & Good & Good & Good & Med & Good & Good & Good & Good & Good & Good \\
\hline
\end{tabular}

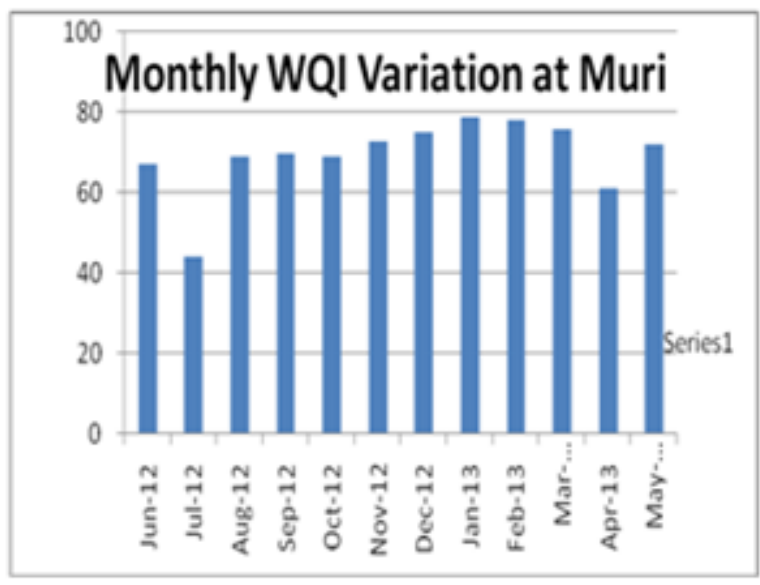

Figure-1

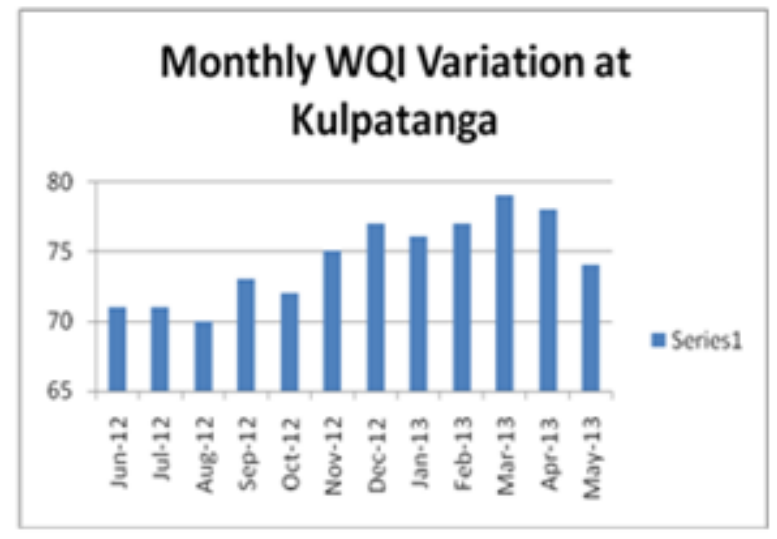

Figure-3

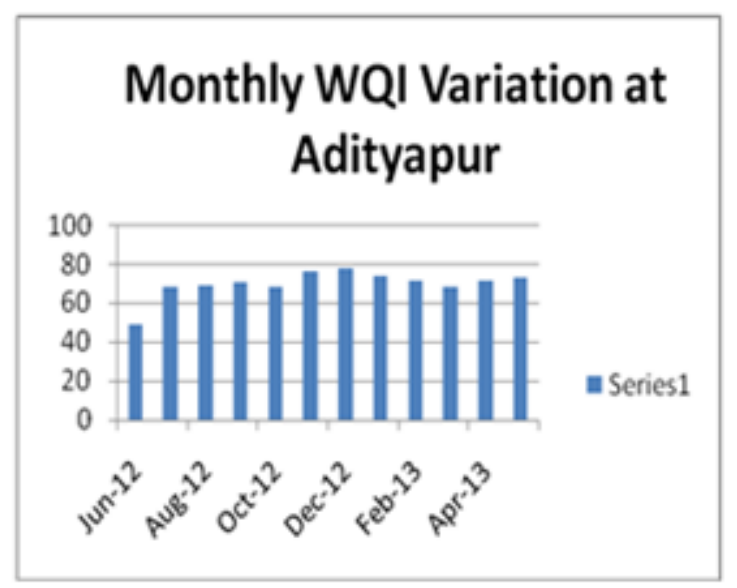

Figure-2

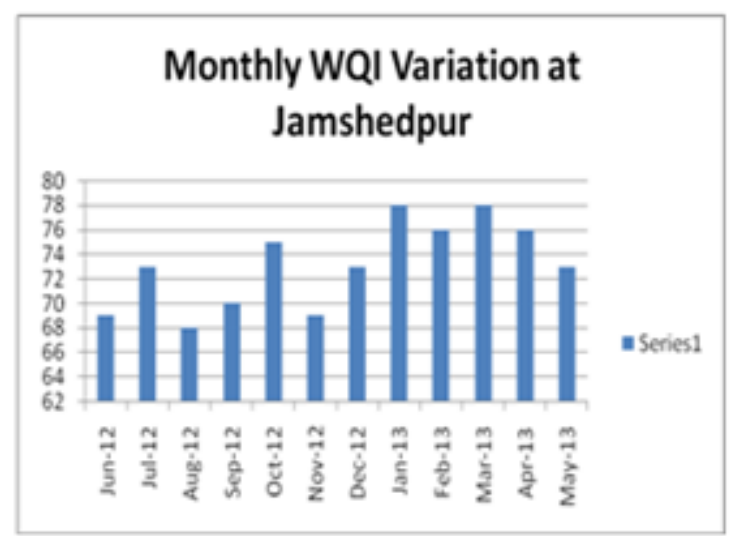

Figure-4 


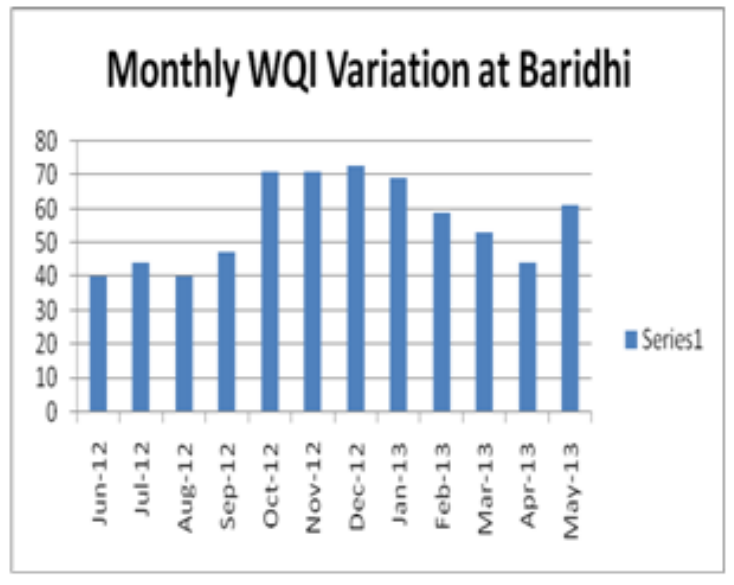

Figure-5

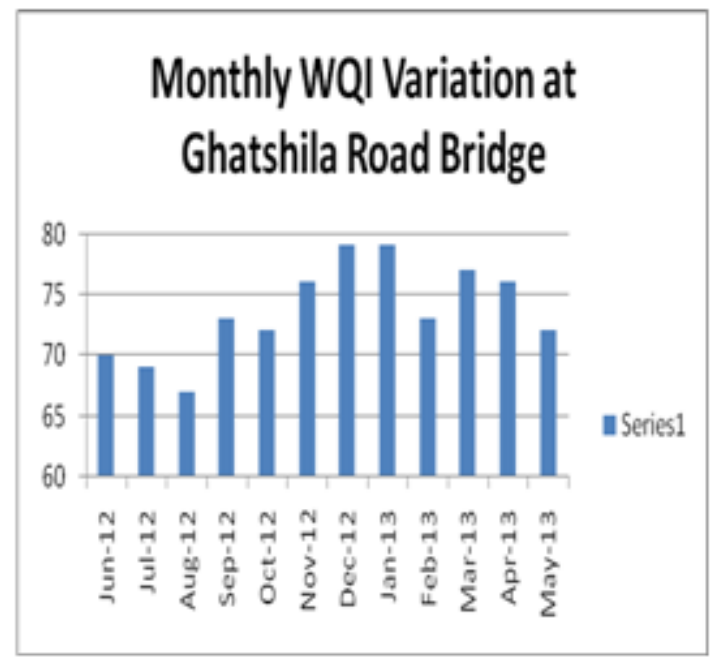

Figure-7

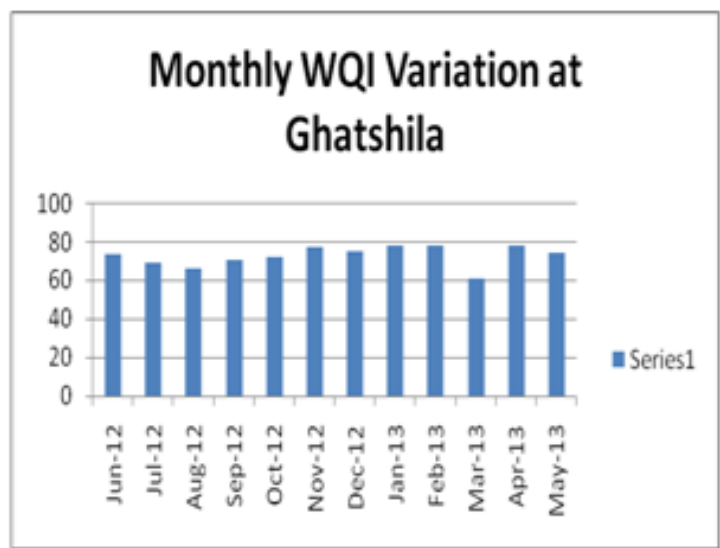

Figure-6

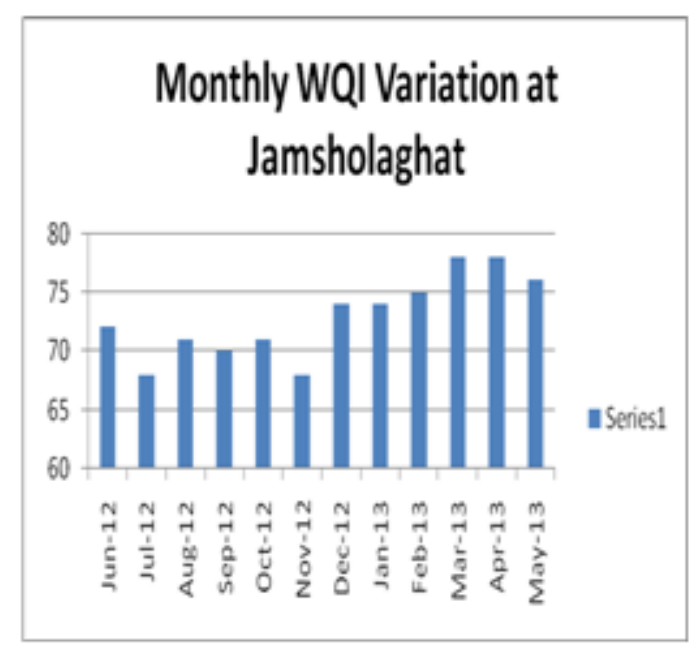

Figure-8 